\title{
ÇAĞDAŞ TÜRK KADINI IMAJI YARATMA SÜRECINDE CUMHURIYET GAZETESININ ROLÜ (1930-1935)
}

\author{
Burak YENITUNA*
}

\begin{abstract}
ÖZET
Cumhuriyeti kuran kadrolar Türk kadınının, sosyal ve kültürel alanlarda, hukuk, eğitim ve çalışma hayatında erkeklerle eşit olmasını hedeflemiştir. Fakat dinsel nedenler öne sürülerek rolleri neredeyse sıfıra indirgenmiş olan Türk kadınını çağdaş bir seviyeye yükseltebilmek için yaşama geçirilen inkılapları, geleneksel yapının etkisinden kurtulamamış bir topluma benimsetebilmek kolay iş değildir. Bu çalışmada, kitle iletişim araçlarının çağdaş hayat tarzları ve modern değerlerin topluma aşılanması için yol gösterici olarak görev yapabildikleri yaklaşımından yola çıkarak, Cumhuriyet döneminde, çağdaş Türk kadını imajı yaratma sürecine Cumhuriyet gazetesinin nasıl bir katkı sağladığı incelenecektir. Türk kadınlarının çağdaş yeni imajının tanıtılması çerçevesinde, gazetenin 1930 ile 1935 yılları arasındaki sayıları taranmıştır. Haber ve makaleler dikkate alınarak yapılan taramada Türk kadınının nasıl kurgulandığı, işlendiği ve nasıl temsil edildiği betimsel çözümleme yöntemi ile incelenmiştir.
\end{abstract}

Anahtar Sözcükler: 1930'lu yıllar, Cumhuriyet dönemi, Türk kadını, Cumhuriyet gazetesi.

\section{IMAGE OF CONTEMPORARY TURKISH WOMEN IN THE PROCESS OF CREATING THE ROLE CUMHURIYET NEWSPAPERS}

\section{$(1930-1935)$}

\begin{abstract}
The staff who founded the Turkish Republic aimed that Turkish woman to be equal with men in social and cultural domains including law, education and work life from the beginning. However it was not an easy task to be able to impose revolutions which aimed to raise the level of Turkish woman to the modern world whom their rights reduced to almost zero level due to the religion related issues. In this study, I analyzed that how Cumhuriyet newspaper provided a contribution to the shaping of the modern Turkish woman image, based on the suggestion that how mass media contributed to the modern life style and values of society. During the study newspapers from 1930 to 1935 scanned to introduce the modern, contemporary image of Turkish women. The study done with a descriptive analysis methodology by scanning and processing news articles to find out how Turkish women fictionalized, mirrored and represented.
\end{abstract}

Keywords: The 1930s, the Republican era, Turkish women, Cumhuriyet newspaper.

\footnotetext{
* Arş. Gör. Dr., İstanbul Ticaret Üniversitesi, İletişim Fakültesi, Medya ve İletişim Sistemleri Bölümü, byenituna@ticaret.edu.tr
} 


\section{Giriş}

18.yüzyıl ile başlayan Türk modernleşme tarihimizde kadının toplumsal konumuna dair tartışmalar Cumhuriyet dönemine kadar genelde yüzeysel kalmıştır. Osmanlı döneminde kadınların toplum içinde daha fazla yer alması ve eğitimlerine verilen önem, Batılı tipte çağdaş bir kadın yaratma amacı taşımaktan çok geleneksel rollerini ve dinsel konumlarını kaybetmeden bazı ayrıcalıklar tanınmasından ibarettir. Yani ilk reformlar kadının ikincil konumunu değiştirmemiştir. Osmanlı'nın yıkıntılarından yeni bir cumhuriyet kuran kadrolar, giriştikleri modernleşme projesinde, geçmiş deneyimlerin bazen aksine ve bazen ise yakın doğrultuda, Türk kadınına büyük önem vermişlerdir. Durna'nın da belirttiği gibi (Durna, 2009: 87) bu önemin altında yatan en büyük neden Türk kadınlarının, modernleşmenin bir simgesi olarak algılanmasıdır. 1924’ten siyasi haklarının tamamlandığı 1934 yılına kadar yapılan bütün inkılapların kadının toplumsal konumunu doğrudan ya da dolaylı olarak etkileyen bir yönü bulunmaktadır. İnkılaplar kadının yasal olarak ikincil statüsünü ortadan kaldıracak ve onları yurttaş haline getirecek bir temel oluşturmuştur ve bu temel toplumun üst katmanları tarafindan hızla kabul görmüştür ama yeniliklerin, dinsel geleneğin etkisi altında yaşayan kitlelerce benimsenmesi pek kolay değildir.

Kitle iletişim araçları, birey veya kitlelerin siyasi tercihlerini etkileyebilir. Belirli konulardaki kanaatlerinin veya tutumlarının değiştirilmesine ve yaşam biçiminin dönüşümüne etki edebilir. Onların sahip oldukları bu güç, genellikle iletişim kuramcıları tarafından "potansiyel birer eğitim ve ikna aracı" olarak değerlendirilmelerine neden olur (Nalcığlu, 2004: 29). 1930'lu yılların en etkin kitle iletişim aracı gazetelerdir. $\mathrm{Bu}$ bağlamda çalışmamızda, Lerner'in, 'toplumda değişmesi istenen eski değer yargıları ve geleneklerinin yerine yeni değerler yerleştirebilecekleri” görüşünden hareketle Türk basınının önde gelen gazetelerinden biri olan Cumhuriyet gazetesinin, çağdaş Türk kadını imajı yaratma sürecindeki rolü incelenecektir. 


\section{Cumhuriyet Gazetesinin Önemi}

Basın, çoğu zaman onlara sahip olan güçlerin ideolojik ve siyasal çıkarlarına göre toplumu yönlendirmede kullandıkları araçlar durumundadır (Güngör, 2011: 195). Mustafa Kemal Atatürk, basının kitleler üzerindeki etkisini iyi bilen bir liderdir. Milli Mücadele dönemi boyunca Anadolu'nun örgütlenmesinde gazeteleri kullandığı ve hatta bizzat kendi kaleme aldığı yazılarla kamuoyunu etkilemeye çalıştığı bilinmektedir. Yunus Nadi ise tecrübeli bir gazetecidir ve bir gazetenin başarıya ulaşmasında okuyucusuyla kurduğu sağlam ilişkinin bilincindedir. Cumhuriyet gazetesi bizzat Atatürk'ün talimatıla kurulur. "Cumhuriyet gazetesi aydınlanma devrimi gazetesi" der İlhan Selçuk. Cumhuriyet ilan edildikten kısa bir süre sonra İstanbul'da, Ankara'daki hükümetin propagandasını yapacak bir gazeteye ihtiyaç olduğunun fark edilmesiyle temelleri atılır. Mustafa Kemal, İstanbul'daki propaganda çalışmalarını başlatmak için Yunus Nadi’ye bir görev verir: "Çocuk, kalk Ístanbul'a git, orada Pembe Konak var, orada Cumhuriyet gazetesini çıkar ve Ankara'nın sesi orada duyulsun. Duyulsun bir şeyimiz olsun, naşit-i efkârımız olsun”" (Özgentürk, 2008, 333-334). 7 Mayıs 1924'te yayın hayatına başlayan gazete, hilafet propagandalarının yapıldığı ve Cumhuriyet karşıtı yazıların yayımlandığı İstanbul'da sağlam bir kamuoyu yaratmak için mücadele vermeye başlar (Köktaner, 2005: 1314-16-21).

Türkiye'de cumhuriyet'in ilanından 1930'lu y1llara kadar uzanan dönem yeni devletin temellerinin atıldığı ve inkılapların birbiri ardına geldiği dönemdir. Zürcher'e göre Halk Firkası'nın kuruluşunun ilk altı yılında (1923-29) Kemalist politikaların desteklenmesi için halkı teşvik etmek gibi bir çaba çok kuvvetli değildir (Zürcher, 2012: 95). Fakat 1930'lardan itibaren artık ink1lapların ve rejimin yerleştirilmesi faslına geçilir. Halk Fırkası, toplum üzerinde artık daha etkin bir rol oynamaya başlamıştır (Tazegül, 2005: 103). Bu yıllarda Türkiye'de muhalefetin tamamen susturulduğu ve siyasetin tek parti ile özdeşleştiği bir dönem yaşanmaktadır. Serbest Cumhuriyet Fırkası denemesi ve hemen ardından patlak veren Menemen olayı gibi toplumsal çalkantılar gerilimi arttırmış ve muhalif bir sese tahammül ortadan kalkmıştır. Dolayısıyla muhalefete izin verilmeyen bir ortamda, Türk basınının güdümlü bir çerçevede yaşamını sürdürdüğünü hatırlamak gerekir. 
Şirin, yaptığı araştırmada (Şirin, 2010: 133) bu güdümlü çerçeveyi, gazetelerin mevcut iktidarın yanında ve “Kemalizm'in telkin ve propaganda aracl” olarak kullanıldığg şeklinde değerlendirmektedir. Daniel Lerner'e göre kitle iletişim araçları, geleneksel toplumsal değerlere sahip olan insanlara eski adet ve alışkanlıkların yerine modern toplumun değerlerini aktarmak için görev yapabilirler. Bu sayede değişmesi istenen eski değer yargıları ve geleneklerinin yerine yeni değerler yerleştirilebilecektir (Yaylagül, 2006: 75). Modern bakış açılarını edinme ve onları ifade etme noktasında, Lerner'e göre kitle iletişim araçları çağdaş hayat tarzlarının benimsenmesi sürecinde yol gösterici bir rol alabilirler (Altun, 2011: 88). Bu bağlamda değerlendirildiğinde, 1929 yılında Cumhuriyet gazetesinin düzenlediği güzellik yarışması, bir İslam toplumunda ilktir. Gazete, güzellik yarışmasının sürecini ayrıntılı olarak verir. Ahmad'a göre bu kesinlikle ticari bir olay değil, siyasal bir olaydır ve bir topluma yenilik getirmenin bir başka yoludur (Ahmad, 2009: 108). Cumhuriyet döneminde devrimlerin her biri radikal değişiklikler içermektedir ve eğitim seviyesi çok düşük olan halkın bu reformları kabullenmesi oldukça zordur. O dönem kamuoyu oluşturma işlevinde basının büyük bölümü Mustafa Kemal'in yanında yer alsa bile Köktaner'e göre Cumhuriyet gazetesinin bu bağlamda ayrı bir önemi vardır (Köktaner, 2005: 68). İlk güzellik yarışmasından da anlaşıldığı üzere Cumhuriyet gazetesi, Lerner'in yaklaşımlarına uygun bir yayın politikası içinde faaliyetlerini sürdürmüştür.

\section{Araştırma Bilgisi}

Bu çalışmada 1930 ile 1935 yıl aralığı temel alınmıştır. Bunun en önemli nedeni sözünü ettiğimiz tarihler arasında Türk kadınları açısından (1930 yılında Belediye Meclisi, 1934 yılında ise Millet Meclisi'ne seçme ve seçilme hakkı) yaşanan önemli gelişmelerdir. Cumhuriyet gazetesinin tercih edilmesinin sebebi ise literatürde genel kabul gören, devrimlerin yaygınlaştırılmasındaki öncü rolüdür. Diğer etken ise dönemin en çok tiraj alan gazeteleri ${ }^{1}$ arasında yer almasından

\footnotetext{
${ }^{1}$ Cumhuriyetin ilanından önce \%5'lerle ifade edilen okuma yazma oranı, cumhuriyet dönemi ile birlikte başlatılan eğitim seferberliği sayesinde 1927 yılında \%10,7’ye ve 1930-39 yılları arasında kademeli olarak \%22,4'lere yükselmiştir (http://www.muhtesemkaynak.com/59.pdf). Dolayısıyla düşük olan bu oranlar dikkate alındığında gazetelerin de 1930 'lu yılların başında çok yüksek tirajlara sahip olmadığı anlaşılacaktır. Rıfat N. Bali'nin araştırmasına göre, Cumhuriyet gazetesi 1931 yılının Mart ayında 14.000, Nisan ayında 14.375 tiraja sahipken 1932 yılında tirajını 20.000'e çıkarmıştır. Yine Akşam gazetesinin, 1931 yıııın Mart ayında 13.000 tiraja
} 
kaynaklanmaktadır. 1930-1935 yılları arasında gazetenin içeriği oldukça renklidir. Karikatürler, tefrika romanlar, kadın - moda sayfaları veya fotoğraflar gazetenin Türk kadınına bakışı hakkında çok fazla veri içerir ve her biri ayrı ayrı birer çalışma konusu yapılabilir. Fakat her birinin tek tek incelenip bu çalışmaya sı̆̆dırılması mümkün değildir. Dolayısıyla haber ve makaleler dışındaki herşey kapsam dışında tutulmuştur. Metinlerin incelenmesinde betimsel çözümleme yöntemi kullanılmıştır. Bu yöntem, Tazegül'ün de belirttiği gibi (Tazegül, 2005:156) ilk gözlemlerden yola çıkarak olgulara eşlik eden özellikleri betimlemeyi amaçlayan bir araştırma türüdür. Walcott, veri analizi sürecinde üç farklı yöntemin izlenebileceğini belirtmektedir. Bu yöntemlerden ilki, alandan toplanmış verilerin rapora olduğu gibi yansıtılmasıdır. Yani araştırmacı görüşme kayıtları, alan notları veya metinler üzerinde yapmış olduğu çalışmalardan elde ettiği verileri blok aktarmalar yaparak çalışmasına yansıtmaktadır. İkinci veri analiz yöntemi ise ağırlıklı olarak birinci yöntem üzerine inşa edilmektedir. Bu aşamada veriler dikkatli ve sistematik olarak bir çözümlemeye tabi tutulmaktadır. Bu sayede veriler içerisindeki anahtar faktörler ortaya konulurken veriler arasındaki ilişkiler de tanımlanmaya çalışılır. Üçüncü çözümleme yöntemi ise önceki iki yöntemin yorumlanması sürecine denk gelmektedir. Burada incelenen konuya ilişkin olarak araştırmacı kendi öznel yorumlarını ortaya koymaktadır (Özdemir, 2010:331). Walcott bu üç yaklaşımın birbirinden tamamıyla bağımsız olamayacağını kabul etmektedir. Dolayısıyla "Betimleme", "Analiz" ve son olarak gözlenen verinin ne anlama geldiği sorusunun sorulduğu "Yorumlama" süreçleri ile neden-sonuç ilişkileri irdelenerek ve anlamlı bir bütün ortaya çıkarılarak bir takım sonuçlara ulaşılması hedeflenmektedir (Yıldırım ve Şimşek, 2005: 222-224). Yapılan çözümlemede 1930 ile 1935 yılları arasındaki dönemde Türk kadınlarına yönelik düşünceler tespit edilmeye çalışılmış, çağdaş Türk kadınının nasıl kurgulandığı ve okuyucuya sunulduğu Cumhuriyet gazetesi üzerinden tespit edilmek istenmiştir.

sahipken Nisan ayında 12.900 ve 1932 yıında 20.000 tiraj elde ettiği görülmektedir. Hâkimiyeti Milliye (1934'ten sonra Ulus) gazetesinin ise 1931 Nisan ayından önceki tirajlarına ulaşılamamıştır. Ancak Nisan ayında 5500 olarak belirlenen tirajının 1932 yılında 25.000'e ulaştığı tespit edilmiştir. (Bali, t.y.) Tirajlara bakıldığında gazetelerin ulaştığı okuryazar olan ya da olmaya başlayan kitleyi toplumun bütünü olarak algılamamak gerekir. Diğer taraftan okuryazar oranının artmasıyla gazete tüketiminin de giderek arttığını söylemek mümkündür. 


\section{‘Cumhuriyet'in Arzu Ettiği Çağdaş Türk Kadını}

Osmanlı İmparatorluğu'nda eğitim olanaklarının bulunmadığı, sosyal yaşam içinde görünmediği, pek çok alanda din açısından bir engel olmasa da, kadınlar için kapıların kapalı tutulduğu (Tanilli, 2006:116) dönemler Tanzimat ile birlikte kırılmaya başlar. Tanzimat'tan İkinci Meşrutiyet'e uzanan dönem boyunca hangi akımdan etkilenirse etkilensin, hemen hemen bütün aydınlar kadınların eğitim hayatında aktif olarak yer almasinı ve kamusal alanda belirmesini savunarak ortak noktada buluşurlar. Fakat amaç Osmanlı kadınlarına yeni bir kimlik kazandırma çabasından ziyade, geleneğin dışına çıkmadan ve dinsel unsurları göz ardı etmeden Doğu-Batı sentezli bir kadın kimliği oluşturmaktır (Kocabaşoğlu, 230, 231). Egemen olan görüşlerde kadınlar bir yandan toplum hayatına entegre edilmek istenirken diğer taraftan kadınların nasıl iyi bir eş, bir anne, eşine itaatkar ve yardımcı birer varlık olabilecekleri tartışılmaktadır. II. Meşrutiyet dönemi ile birlikte Batılılaşmacı aydınlar ise kadınların sadece "dişi”” varlıklar olarak tanımlanmalarına karşı çıkarlar. "Kadının valide, zevce, hemşire, refika ve muhibbe sıfatlarlyla daima erkeğin yarım mevcudiyetini temsil ettiğini anlamalıyı” ifadelerine Bizde Kadın adlı kitabında yer veren Ahmet Cevad, erkeklere ögütlerde bulunmakta ve kadınların cariye olarak ya da tutsak ederek yaşatmanın gereksizliğini vurgular ama bir şartı vardır; erkek bizzat bekçi ya da gözcü olmak durumundadır (Durakbaşa, 1998: 40). Kadına verilen bu şartlı özgürlük bir görev bilinci taşımaktadır. Kandiyoti'nin de belirttiği gibi (Kandiyoti, 2011:106) kadınların toplumsal hayattan dışlanmaları ve eve kapatılmaları, insan haklarının çiğnenmesi ile ilgili olarak algılanmamış, üretken olmayan bireyler yarattığı ve toplumun ilerlemesine mani olduğu gerekçesiyle eleştirilmiştir.

Cumhuriyet dönemine geçişle birlikte Türk kadınlarının yaşam koşullarında artık gözle görülür bir değişim başlar. Türkiye'de devrimlerin birbiri ardına geldiği yıllarda; 1923 yılında davet edildikleri Birinci İzmir İktisat Kongresi'nden sırasıyla 1924 Tevhid-i Tedrisat, 1925 Şapka ve Kılık Kıyafet Kanunları, 1926 yılındaki Medeni Kanun, 1930'da Belediye ve nihayet 1934'te Milletvekili Seçme ve Seçilme esaslarını yeniden düzenleyen anayasa değişikliğine kadar geçen sürede kadın hakları konusunda geri döndürülemez bir sürece girilir. Oysa daha 30 y1l önce, Avrupalı 
dükkânlara uğramalarını önleyen, arabanın içinde bile peçe takmaları zorunluluğunu getiren, çarşaflarının uzunluğundan ayakkabılarına kadar giyim ve kuşamlarının bir bir belirlendiği, sokağa tek başlarına çıkmaları halinde tutuklanmalarının öngörüldüğü nizamnamelerle (Tanilli, 2006:119-120) yaşamak durumundaydılar. Türk kadınlarının geçmişteki kayıplarının telafisi tüm eleştirel görüşlere rağmen Cumhuriyet rejimi sayesindedir. Devrimler sadece siyasal hayat1 etkilemekle kalmamış, Göle’nin de belirttiği gibi (Göle, 2011: 83) devletin yapısını değiştirmekten öte, yaşam şekillerine, davranış biçimlerine, gündelik alışkanlıklara nüfuz etmek amacını da taşımıştır. Bu yüzden de daha ilk yıllardan itibaren eldeki tüm araçlarla geri kalmışlığa karşı savaş açılırken toplumun geleneksel kalıplarının yıkılması için de çaba harcanmıştır. Ahmad, Mustafa Kemal'in kadınlarla ilgili düşüncelerini topluma asla zorla kabul ettirmeye çalışmadığını ileri sürer. Mustafa Kemal'in, peçeyi kaldırdığı için Afgan Kralı Emanullah'ın devrileceğini önceden bildiğini belirten Ahmad'a göre Kemalistler başka bir yol seçmişler ve tutucu muhalefeti çeşitli manevralarla zayıflatmak istemiş̧lerdir (Ahmad, 2009: 108). Türk basını bu manevralardan biri midir? Şüphesiz öyledir. Örneğin Cumhuriyet gazetesinin 1929 yılında düzenlediği güzellik yarışması halkın kültürel kalıpların değiştirilmesi amacını taşır. 1932 yılında Keriman Halis’in Dünya Güzellik Kraliçesi unvanını kazanması Atatürk'ün yüksek olmasını istediği Türk kadını idealinin vücut bulmuş bir kanıtı gibidir. Bu başarıdan sonra; “Türk Soyu’nun dünyadaki en güzel soy olduğunu tarihten bildiğim için, Türk kızlarından birinin dünya güzeli seçilmiş olmasını çok tabii buldum” (Goloğlu, 2009:165) sözleri boşuna değildir. Bu bakımdan 1930'lu yıllar denilince gazetelerin sütunlarında ilk karşılaşılabilecek yazılar güzellik yarışmaları üzerinedir.

Yunus Nadi'nin 13 Ocak 1930 tarihde kaleme aldığı "Güzellik ayıp bir şey değildir” başlıklı yazı, erkek egemen görüşün Türk kadınını görmek istediği noktanın bir özeti gibidir. Yazıda, "Türk kadınlı̆̆l hakkında bütün dünyada asırlardanberi birleşen efkâr ve itikadatının artık yeri yurdu kalmamış efsanelerden başka bir şey olmadığını bütün dünyanın hayret gözlerine fiiliyatı ile dahi göstermeli idi. (...) Türk kadınları bütün dünyanın hür hemşerilerinden farksız insanlar haline yükselmişlerdi" vurgusunun yapıldığı fark edilmektedir. Yazıda, güzelliğin ayıp bir 
şey değil, "bilakis bütün dünyanın istediği ve önünde hürmetle ve hayretle eğildiğì" (Nadi, Cumhuriyet: 1930) bir şey olduğu okuyucuya sunulmaktadır. Metinde açıkça anlaşıldığı üzere kadınlar 'Türk' olmanın övüncü içinde ve kadın olmalarının deneyimini ulus devlet çatısı altında yaşamaya çağırılmaktadır. 'Güzellik' kavramı ise geleneksel anlayışın aksine bir mahrem olarak değil tam tersine saygı duyulan ve hayret uyandıran bir unsur olarak kurgulanmıştır. 30 Ocak 1930'da ise Nadi, "Haremden gümüş köprüye" başlığını attığı başyazısında Fransız Le Jurnal gazetesinin Türkiye hakkında yazdığı bir makaleden örnekler verir. M. Maurice de Waleffen'in, "Dün haremde doğup yarın opera balosunun gümüss köprüsünde dikilecek olmak... Bu bir milletin tekâmülünde ne büyük bir mesafe arzeder!” ifadelerini aynen aktaran Yunus Nadi, aslında köprüden geçecek olanın Türkiye ve Türk inkılabı olduğunu belirtmektedir. Artık "asırlardır ve asırlardır Türk kadınını örten simsiyah perde" kalkmış, Kurtuluş Savaşı'nı kazanmakla yetinmeyen cumhuriyet, kadınlara yeni ufuklar açabilmek için mücadele vermiştir ve Nadi'ye göre bundan sonra Türk ulusunun daha da güçlenmesi kaçınılmazdır. Nadi’ye göre kadın toplumun 'yarısı' olduğu için Türk ulusunun geçmişte güçsüz duruma düşmesi, Türk kadınlarının sistem dışı bırakılmasından kaynaklanmaktadır (Nadi, Cumhuriyet:1930):

Türk Cemiyeti asırlar ve asırlardır mehcur olduğu diğer yarısı ile birlikte meydana çıkmış, artık müterakki insan cemiyetleri içine girmeye hak kazanan haklı bir gururla yeni bir varlığın şaşaasını arzetmeye başlamıştır.

Yunus Nadi, 24 Ocak 1931'de yine güzellik yarışmalarıyla ilgili kaleme aldığı diğer bir yazısında yarışmaları ahlaki bulmayanlara çatarak kadınların artık eski devirlerdeki gibi esir edilemeyeceğini vurgular. Ahlak bekçiliği yapanların, "kadın dört duvar arasında kalın çullar içinde mahpus iken daha ahlaklı idi, yoksa bu haksı hayatına nihayet verilerek alemin içine karıştıktan sonra mı daha ahlaklı oldu?” şeklindeki çıkışlarına karşı Yunus Nadi, “Bir haksızlık varsa o Türk kadınını tabii olan insanlık haklarından mahrum ederek onu dolapların köşesine saklanır metalar haline getirmenin” (Nadi, Cumhuriyet: 1931) neresinin ahlak olduğunu sormaktadır. Namus, geleneksel-çağdaş karşıtlı̆̆ı ekseninde kurgulanarak çağdaş düşünce ve yaşayışın namus anlayışına engel olmadığ belirtilmek istenmiştir. Nadi’ye göre geçmiş dönemlerdeki kadın 'meta' olmaktan öte 
başka bir şey değildir. Bu bağlamda geleneksel toplum yapısındaki 'ahlak' vurgusunun yanlışlığı üzerine okuyucular uyarılmaktadır. Tazegül'e göre ulus devlet oluşturma sürecinde Türk'ün milli karakteri de şekillendirilmeye ve tasvir edilmeye çalışılmıştır. Bu tasvir oryantalist şark imgesinin zıddıdır; dinamik, rasyonel ve dünyevi Türk vatandaşıdır (Tazegül, 2005: 140). Yazılarda farklı konular genelde aynı çerçeve içinde işlenmekte ve "milli kimlik" vurgusu ön plana çıkarılmak istenmektedir. "Türk" kadını da kadınlığını milli bir çatı altında yaşamaya çağırılmaktadır. Ancak geçmiş vurgusu da önemli bir yer tutmakta, geleneksel yaşam tarzı ve inanışlar, 'istenmeyen' ve açıkça 'kurtulunması gereken' bir tehlike olarak sunulmaktadır. Fakat asıl çelişki de burada başlamaktadır. Yüzyıllar süren ve İslami kültürle beslenen ataerkil anlayış Berktay'ın da belirttiği üzere (Berktay, 1998: 4), yerini daha çağdaş ve batıcı bir ataerkilliğe terk etmektedir. Geçmişten kurtulma söylemini üreten ve ideolojik her aygitla yayanlar yine erkek egemen azınlıktır. Ulusalcı bir söylemle kurgulanan kadın hakları, inkılapları hayata geçirenlerin yanı sıra büyük çoğunluğu erkek olan gazetecilerin de kadınların toplumsal ve siyasal statüleri hakkında yorum ve yönlendirme yapıyor olması bu biçim değişikliğini ortaya koymaktadır. Çünkü aralarında gazetecilerin de bulunduğu Kemalist öncü kadrolar için kadının sosyal zeminde boy göstermesi, belli bir amaç için araçtır ve Berktay bunu, Cumhuriyetin yeni ulusal karakterinin ortaya konulma çabası olarak yorumlamaktadır. Geçmişle bağlarını koparmaya çalışan yeni Cumhuriyet, Osmanlı gibi dine dayalı değil ulusa dayalı bir ülke olmayı hedeflemiştir. Bu bağlamda kadının da bir 'simge' olarak kullanılması kaçınılmaz olarak görülmüştür. Gazetelerin bu simgeyi kullanmada ve Türk kadınının yeni imajını topluma sunmada çok çeşitli kaynaklardan yararlandıkları fark edilmektedir. Dış basın taraması ile elde edilen haberlerin Cumhuriyet gazetesi sütunlarında yer bulması buna en iyi örnektir. 14 Haziran 1930 tarihli nüshada, Paris’te çıkan Le Miroir du Monde dergisinin Türk kadını ile ilgili yayımladığı bir makaleyi gazete sütunlarına taşımıştır. Makaleye göre, Fransız gazeteci M. Villy Sperco, Türkiye'ye gelerek gözlemlerde bulunmuş ve Türk kadınının gelişimine hayran olmuştur. Makalede Sperco'nun, “Eski naşatlar ve ancak gözlerini gösteren çarşafla örtülü siyah hayaller tamamen kaybolmuştur. Ĕger Ístanbul'un tenha dar sokaklarında yüzü kapalı kadınlara tesadüf edilecek olursa bunların altmış yaşını geçkin olduklarına şüphe edilmemelidir” (Cumhuriyet, 1930) 
ifadelerine genişçe yer verilmiştir. 16 Kasım 1932'de Times gazetesinin Türkiye muhabiri tarafından kaleme alınan bir makale haberleştirilmiştir. Times muhabiri, Türkiye'de kadın avukat ve hâkimlerin artık mahkemelerde görüldügüünü ve kadın güvenlik güçlerine sokaklarda rastlandığını yazar ve on yıl içindeki tüm yeniliklerin Mustafa Kemal sayesinde olduğunu belirtir. Türkiye'de aile hayatının yükseldiği fakat buna karşılık köylerde hala muhafazakârlığın devam ettiğini belirten muhabir, köylü erkeklerin kadınının güzelliğini göstermesine, hukuk sahibi olduğunu düşünmesine tahammül edemediğini vurgulamaktadır. Muhabire göre köylerde açılmakta olan Halkevleri sayesinde köyde yaşayan erkek ve kadınların yeni ideolojiler çerçevesinde eğitildikleri için kısa zaman sonra 'çaresizlikleri' yok olacaktır (Cumhuriyet, 1932). Yine buna benzer bir makaleye 3 Şubat 1933 tarihinde rastlamaktayiz. Cumhuriyet gazetesi, The Times ile Amerikan The Literary Digest dergilerinin Türk kadını hakkında yayımladıkları makalelere yer vermektedir. Yazıda The Literary Digest dergisinin, "Eskiden Türk kızı on beş yaşına geldi mi peder ve validesinin kararıyla kendisinin hiç görmediği bir erkekle evlendirilirdi. İzdivaçtan sonra da Türk kadınının atisi müemmen değildi. Çünkü kocası istediği anda kendisini boşayabilirdi" ifadelerine yer verilir. The Times'ın ise “Türkiye'de Cumhuriyet rejimi (...) çarşaf giymek mecburiyetini kaldırdı, (...) Bugün Türk kadını erkeklerle aynı hukukta darülfünunlara kabul ediliyor, Türk kadını hemen hemen her türlü mesleklere girebiliyor. Belediye intihaplarında Türk kadını rey veriyor" ifadelerine vurgu yapıldığı fark edilmektedir (Cumhuriyet, 1933). Her iki makalede de geleneksel-çağdaş karşıtlığı oldukça belirgin bir biçimde sunulmuştur. 20 Kasım 1933 tarihinde ise Cumhuriyetin onuncu yıl kutlamalarına bazı Amerikan ve Fransız gazetelerinin yer verdiği belirtilerek matbuatın "Türkiye'deki değişikliği bir mucize olarak" sundukları vurgulanmıştır. A.Reşat imzalı yazıda, Fransız Illustration gazetesinin Türk inkılabına uzunca yer verdiği ve hayranlık içinde şöyle yazdığ vurgulanmaktadır (Reşat, Cumhuriyet: 1933): "Ebedi Havva bir kere daha zafer kazandl."

Gerçekten de, Türkiye'de esen değişim rüzgârı o dönemde ülkeye gelen yabancılarda şaşkınlık yaratmıştır. Cumhuriyet rejimi sosyal ve kültürel alanlarda yeni düzenlemelere giderken, özellikle kadınların Batı'daki hem cinslerine 
benzemesi için çaba göstermekte, politik ve ekonomik yakınlaşma sürerken sosyal ve kültürel yakınlaşmanın da sağlanmasını hedeflemiştir (Kırkpınar, 1998: 19-21). Afet İnan, Ulus gazetesindeki bir makalesinde Türk kadınından şu ifadelerle bahseder: "Tipi güzeldir. Başını örter, güneşten korunmak için. Türk köylü kadını hiçbir zaman yüzünü, Osmanlı Imparatorluğunda dahi şehirlerde olduğu gibi kapamamıştır." İnan, Osmanlı döneminin en büyük hatalarından birini Türk kadınını bilhassa şehirlerde sosyal hayattan uzaklaştırması olarak belirtirken, aynı devirde erkeklerin de dini ve taassubu kadına karşı şuursuzca kullandıklarını vurgulamaktadır (İnan, Ulus: 1937). En eski Türk toplumsal yaşamında böyle bir eşitlik var mıdır? Araştırmalara göre eski Türk topluluklarında kadın aile içinde eşit haklara sahiptir ve giyimi bakımından kapalı değildir. Orhun Kitabeleri üzerindeki incelemelerde, evli kadınların kutsal sayıldıkları, devlet yönetiminde kadınların bulunduğu ve en üst konuma kadar yükselemeseler de iktidarı büyük çapta paylaştıkları anlaşılmıştır. Orta Asya'da Türk kadını iyi bir binicidir ve çoğu zaman eşiyle birlikte savaşlara katılır. Anadolu birliğinin Osmanoğulları tarafından kurulmasından önce Türkmen kadınlarca kurulan Bacıyan-1 Rum Teşkilatı, 14.yüzyılda, Anadolu'nun sosyal, siyasal, kültürel ve ekonomik yapısını Ahilik Teşkilatı ile birlikte etkileyen en önemli unsurlardan biri olmuştur. Oktar'a göre Osmanlı'nın ilk dönemlerinde özellikle Anadolu'nun kırsal bölgelerinde yaşayan Türk kadınları, geleneksel özgürlüğünü kısmen de olsa sürdürmüş fakat İstanbul'da yaşayan kadınlar İslami kültürün etkisiyle padişah buyrukları ile şeyhülislam fetvalarının gölgesinde kapalı bir yaşama sürüklenmiştir (Oktar, 1998:18-19). İşte, Kemalist kadroların istediği Türk kadın tipi, kökleri Orta Asya'ya uzanan Anadolu Türk kadın tipi ile örtüşmektedir. Toska'nın da belirttiği gibi (Toska, 1998:78) ideal kadın tipi, kökleri, kadının ailede, toplumda ve devlet idaresinde erkekle eşit haklara sahip olan Anadolu kadını olmalıdır. Kandiyoti'ye göre de (Kandiyoti, 2011: 97) bu durum Türk tarihinin yeniden yorumlanması süreci ile yeni devletin ideolojik seferberliğe başlamasını gerektirmiştir. Cumhuriyet gazetesi de ideolojik seferberliğin bir aracı olarak arzu edilen amaca uygun şekilde, Türk kadınının geçirmesi gereken dönüşümü tarihsel geçmişle ilişkilendirilmekte ve kadının yeni imajını bu geçmişle meşrulaştırmaya çalışmaktadır. Örneğin, 1 Eylül 1932 yılında Yunus Nadi’nin kaleme aldığı makaleye göre Türkler, İran ve Bizans'la yakın ilişki içindeydiler. 
Türklerin hakiki geçmişini anlamak için Yörük ve Türkmenlere bakmanın yeterli olacağını belirten Nadi, "bunlarda kadın esir değil, alabildiğine sıkı fikı örtülü değil, evin ve ailenin işlerinde büyük söz sahibi, hülasa tam manasiyla ece olan bir hanımefendidir" demektedir. Türk kadınının ikinci plana atılmasının Türklerin geleneklerine aykırı olduğunu vurgulayan Nadi’ye göre inkılaplar, “Türk'ün asıl kendi milli an 'anesini ihya ve iade etmek yolunda bir harekettir" (Nadi, Cumhuriyet: 1932). Nadi, Türklerin geçmişini, Osmanlı olarak değil, Osmanlı öncesindeki yaşam şekilleri olarak görmektedir. F. Selçuk imzalı bir başka makalede geçmiş dönemlerle bağların kopartılmaya çalışıldığı şu ifadelerden anlaşılabilmektedir (Selçuk, 1933):

Türklerde kadının Cumhuriyetten evvelki vaziyetini de çok iyi hatırlarsınız. O zamanlardaki kadın sadece bir esir ve bir zevk ve eğlence aletinden başka bir şey değildi. (...) Türk kadını hakkını isterken ecnebi kadınları gibi bugüne kadar asla malik olamadığı bir hakkı isteyecek değil, eskiden malı olup da sonradan kaybolan hakkını dava edecektir.

Halil Nemutullah Öztürk ise tarihin değişik dönemlerinde ulusların yanlışlıklara düştüğünü belirterek kadının toplumsal hayattan dışlanmasını, "erkekle kadın arasında birliği kaldıran ulusların ne yaman bir gerilik, ne öldürücü bir yokluk içine düştügünü acun tarihi bize gösteriyor” ifadeleriyle yorumlamaktadır. Türk tarihine bakıldığında geçmişte kadınla erkek arasında eksiksiz bir birlik bulunduğunu belirten Öztürk, “Topluluk diriminde hiçbir iş yoktur ki orada kadın, erkekle birlikte olmasın, erkekle birlikte çalışmasın, en güç, en korkulu işlerden kadın erkeğin yanında bulunmasın..." demektedir. Öztürk makalenin devamında Osmanlı döneminin eleştirisine girmiştir (Öztürk, Cumhuriyet: 1935) :

Türk türesi böyle olmuş, ulus varlığının yarısını kadın dirimi bütünlemekte bulunmuşken sonradan yapma Osmanlılığın kadına karşı aldığı Türk özile hiç te uymayan aykırı yağı, duruş ulus diriminde yüz yıllarca ve yüz yıllarca budunumuzu geriletmiş, şenlik acununda kendini hor etmiş, sanki kişilik diriminden bütün bütün yoksul kötürüm bir kılığa sokmuştu. Çünkü Osmanlılığın üst bölümü olan Arablık kadını hiçe sayar, kadını oyuncak yerine kor, ona kişilik dirimini çok görürdü. Kız çocuklarını diri diri toprağa gömen bir ulustan kadın için hiçbir iyilik beklenir mi?

Öztürk’e göre Türk inkılabı, Türk kadınını çağlar önceki durumuna geri döndürerek öz varlığına yaraşır bir hayat yaratmıştır. Şükufe Nihal'in 15 Nisan 1935 tarihinde kaleme aldığı "Dünyanın her yerinde kadının kurtuluşu yakındır" başlıklı makalede benzer temalar hakimdir. Nihal okuyucusuna şöyle seslenmektedir: "Türk kadınını hala kafes ardında sanan; Türk evlerinde harem daireleri düşünen 
yabancılar şaşakalsın. Bizde kadın meselesi artık eskimiş, modası geçmiş bir meseledir." Nihal, dünyadaki büyük medeniyetlerin en parlak çağlarını kadınların erkeklerle eşit statüde oldukları çağlar olduğunu belirterek kadını dini gerekçeler öne sürerek küçültenleri eleştirmektedir (Nihal, Cumhuriyet: 1935):

Geri insanlar ve bazı dinler kadını küçültmüşlerdir. Kadına hiç bir hak vermeyen; Havva'nın insanın felaketine sebep olduğunu söyleyen Hıristiyanlıktan önce, kadının tanrı olarak tanındığını görüyoruz. Afrodit, Sibel, Edda, Freya ve eski Türklerin Omay’ı buna birer örnektir. Bilgisiz hocaların ve hadbinlerin kafasıyla değişmemiş olan gerçek İslam dininin de kadına ne kadar değer verdiğini hepimiz biliriz.

İnkılapların bireyleri sadece yüzeysel ve biçimsel olarak değil, bütüncül bir yaklaşımla ve zihinsel olarak değiştirmesi hedeflenmiştir. Cumhuriyet gazetesinin de bu zihinsel dönüşümü sağlayabilmek için büyük çaba harcadığı fark edilmektedir. Ancak Kırkpınar'ın da belirttiği gibi 'toplumsal gerçekler, teorilerle her zaman uyuşmaz” (Kırkpınar, 1998: 16). Ona göre inkılapçı kadrolar her ne kadar kuramsal olarak toplumu değiştirmeye çalıştıysa da Türkiye'nin geneline aynı boyutta ulaşabildiklerini söylemek mümkün değildir. $\mathrm{Bu}$ bağlamda yaygınlaştırılmaya çalışılan kadın imajının, iletişim araçlarının yaygın olarak kullanıldı̆̆ı ve okumayazma oranının yükseldiği kentlerde daha çok orta ve üst sınıflarca kabul gördügüunü ama buna karşın iletişim olanakları kısıtlı olan doğu ve güneydoğu bölgelerinde pek de etkili olmadığını söylemek doğru olur. $\mathrm{Bu}$ durum bir bakıma kitle iletişim araçlarının Türk kadın imajı yaratmadaki etkinliğinin anlaşılmasına da yardımcı olur. Diğer taraftan kentli orta ve üst konumlardaki kadınların uzman meslek dallarında yetişmesi ve prestijli mesleklerde yükselmesi de gelecekteki genç kuşaklara rol modeller (Kandiyoti, 2011:77) oluşturması bakımından önemlidir. Bu modellerin oluşumunda basın üstüne düşen vazifeyi yerine getirmekten geri kalmamıştır. Örneğin Cumhuriyet gazetesinin, 9 Ağustos 1930 tarihli nüshasında yer alan bir haberde çalışma yaşamına vurgu vardır. Haberde, “... kendi idarelerini kazanmak için hayata gireli epeyce zaman olmuştu. Fakat daha ziyade içtimai ve idari teşekküllerde çalışmak arzusuyla mesaile karışan hanımlarımız, Cumhuriyetin verdiği serbestiden sonra erkek meslektaşları kadar muvaffak olmanın yolunu bulmuşlardır" (Cumhuriyet, 1930) denilmektedir. Kadınların resmi işlerde dürüstçe hareket ettiklerinin vurgulandığı haberde, Cumhuriyet rejiminin kadınlara güvendiği belirtilmektedir. 17 Ocak 1930'da Muammer Hanım'ın bir Fransız okulunda 
okuduktan sonra sınavlara girerek ilk Türk kadın şöförü olduğu verilmiştir. Şöförlük mesleğinin sadece erkeklerin yapabileceği bir meslek olarak görülmemesi gerektiği ve “Kadınların sinirleri zayıf olduğu” gibi düşüncelerin erkekler arasında yaygın olsa da geçerli olmadığı vurgulanmaktadır (Cumhuriyet, 1930). 16 Mart 1931'de Türkiye'nin ilk kadın operatör doktoru olan Suat Hanım ile ilgili haberi gazete baş sayfadan vermiştir. Haseki Nisa Hastanesi'nde görevli Suat Hanım'ın gece-gündüz demeden tam iki buçuk sene çalışarak başarılı bir operatör olduğu okuyuculara aktarılmaktadır. İlk yaptığı ameliyatın apandisit ameliyatı olduğu belirtilen Suat Hanım'ın seneler geçtikçe daha başarılı hale geldiği, en tehlikeli ameliyatlardan bile başarıyla çıktığı anlatılmaktadır (Cumhuriyet, 1931). 15 Kasım 1933'te 30 yaşındaki Gül Hanım'ın, Aydın'a bağlı Demircidere köyünden ilk kadın köy muhtarı olduğu ve köy halkının bu durumu davul ve zurnalar eşliğinde bir bayram havasında kutladığ (Cumhuriyet, 1933), Türkiye'nin ilk kadın pilotlarından Bediye Hanım'ın havacılığa karşı olan tutkusu 29 Temmuz 1933 tarihinde baş sayfadan verilen haberlerdedir. Övgü dolu ifadelerle zenginleştirilen yayımlara bir örnekte Yunus Nadi’nin, 4 Nisan 1930 tarihindeki yazısından verilebilir. Yazısına "Türk kadını da artık yüzü açık ve alnı yüksek pek mümtaz bir mahlûk olmuş bulunuyor" ifadeleri ile başlayan Nadi'ye göre belediye seçimleri önemli bir adımdır. Ona göre, "belde, cemiyetin medeni manasiye göze görülen en maddi ve bariz şeklidir. (...) belediye intihapları bizce memleket intihabının esasen en hakiki ve en klymetli manasın tecelli ettirecek olan merhaledir." Yani şehirlerini, kasabalarını ve köylerini medeni bir anlayışla idare edebilen ülkeler ileri ülkelerdir ve Nadi, Türk kadınının hizmetlerinde başarılı olacaklarından emindir (Nadi, Cumhuriyet: 1930). 29 Ağustos 1932 tarihli başka bir makalede kadınların değişimi net bir şekilde özetlenirken, Avrupalı kadınların artık Türk kadınlarına özendiği vurgulanmaktadır (Cumhuriyet, 1932):

\footnotetext{
Bugünkü Türk kadını yürüyüşü ile serbest rüzgarlar yaratıyor, iskarpinin ökçesiyle yeni yıllar çiziyor, şapkasını pek zarif giyiyor, eğlence yerlerine gidiyor; fakat aynı zamanda Darülfünuna da devam ediyor, içtimai faaliyete rehberlik ediyor: Avukat, doktor, san'atkar, hakim oluyor, resmi dairelere, şirketlere, ticarethanelere giriyor, muhasip, daktilo, katip, veznedar oluyor, iş hayatında erkeklerle erkek gibi çalışıyor, Avrupai hayata mümkün mertebe sür'atle yaklaşıyor ve varıyor. Kadının plajda, pek zarif mayolarla güneş tedavisi yaptığını, kumsala uzandığını, denize daldığını, mükemmel yüzdügüüü, kürek çektiğini, otomobil idare ettiğini, tenis oynadığını, hasılı umumi harpten sonra zamanın kadın için hazırladığı herşeyden istifade ettiğini ve en şayanı hayret ve takdir olarak erkeklerin gözü önünde hiçbir münasebetsizliği mucip olmadan
} 
cereyan ettiğini de görürsünüz. (...) İşte bunun içindir ki Türk kadını, (...) yeni rejimin en fanatik muhafizı olacaktır.

Her defasında Türk kadınlarının, 'toplumun yarısı' olduğunu belirten Yunus Nadi, 10 Ekim 1933'deki başyazısında Türk kadınlarının artık siyasi haklarını elde etmeleri gerektiğini vurgulamaktadır. Nadi’ye göre insan olmanın gereği Türk kadınının ilk hakkı erkekler gibi hürriyet hakkıdır. Türk kadınları, Nadi’nin ifadeleriyle, "çarşafı yırtarak, umacı klyafetlerinden çıkarılarak" cemiyet hayatına aktif olarak katılmıştır. Aile düzeninde bile erkek kadar kadının da sorumlulukları olduğunu belirten Nadi, okuyucularına şöyle seslenmekte ve siyasal hakların yakında verileceği mesajını iletmektedir (Nadi, Cumhuriyet: 1933):

\footnotetext{
Arkalarında süt emen yavruları günlerce mermi taşıyan Türk kadını bu bizim milli cidalimizin şüphesiz en parlak destanını teşkil eder. (...) Ne zannediyorsunuz?.. Türk kadını hürriyetini kazandı da herşey olupbitti mi? Türk kadınının cemiyet haklarına tesahup etmek hususunda yavaş yavaş katedeceği diğer mesafeler ve dereceler de vardir...
}

Arat'a göre (Arat, 1998: 52-53) Kemalist rejim sınıf çelişkilerini yok etmek istediği kadar cinsiyet egemenliği kavramını da yok etmeyi amaçlamıştır. Ülkenin yıllardır geçirdiği savaşlar ve girdiği bağımsızlık mücadelesi nedeniyle yabancı düşman tehdidi hiçbir zaman zihinlerden silinemeyeceğinden yabanc1 güçlere karşı verilmesi beklenen mücadele, tek meşru mücadele olarak görülmüştür. Bu mücadele doğrultusunda hedeflenen ulusal kalkınma, ancak bütüncül bir yaklaşımla ele alınırsa başarılabilecektir. O nedenle kadınların sosyal, kültürel, ekonomik ve siyasal katılımlarına teşvik edilmesinin yegâne amacı Arat'a göre ulusal gelişmenin bu yöntem üzerinden kurgulanmaya çalışılmasıdır. Cumhuriyet gazetesinin sütunlarında yer alan metinlerdeki vurguların, kadınların bu ulusal 'görev'e çağırılmasından ileri gitmediği anlaşılmaktadır. İnkılaplar, amaçları ne olursa olsun Türk kadınlarına toplum içinde daha geniş bir alana açılmalarına imkân tanımıştır. Gazetenin amacı ise bu imkânları okuyucularına sunarak göreve katılıma katkı sağlamaya çalışmaktır. 30'lu yılların başından itibaren de sosyal görevlerle birlikte siyasi haklarla ilgili konular sürekli gündemde olmuştur. 7 Aralık 1934'te ise Abidin Daver, Türk kadınlarının siyasi haklarını kutlamaktadır. "Türk kadını Büyük Millet Meclisinde" başlığının atıldığı başyazıda, Atatürk'ün kadını karanlıktan kurtardığı belirtilirken özellikle köylü kadınlara yönelik bir yüceltme vardır. Anadolu köylü kadını 'vatanın temeli' olarak vurgulanmaktadır. Daha önce haber ve makalelerde de örneklerini 
verdiğimiz gibi bu yazıda da Daver, Osmanlı döneminden önce Türk kadınlarının toplumsal yaşamda erkekle beraber yürüdügünü ancak Osmanlı döneminde geri plana itildiğini belirterek bunun büyük bir haksızlık olduğunu vurgulamaktadır. Ancak Daver'e göre Anadolu köylü kadını, kentli kadınlar gibi hareme kapatılmamış ve erkekle yanyana çalışmaya devam etmiştir. Daver'in makalesinde Anadolu köylü kadını yüceltilmektedir:

Köy anası orak başında doğurur, yavrusuna döğen üstünde süt verir. İlk gün 1şı̆̆ında yuvasından çıkar; karanlığa kadar beli dorulmaz; alınteri dinmez. Eker, biçer, öğütür, pişirir. Kerpiç yoğurur, taş yontar. Anadolu, yarıyarıya kadın emeği üstüne dayanmaktadır. Kurtuluş savaşında köy kadını askerlik etti. Ateş boyuna giden yollar kağnı süren analarla doluydu. Bu analar, cephede dövüşen Türk erkeklerine erzak, silah taşıyorlardı. Türk kadını, kağnılar almayınca topçu cephanesini omuzlarına yükleniyor, bir eliyle yavrusunu sürükleyerek yağmur, çamur, kar, sıcak dinlemeden yürüyüp gidiyordu. Böyle fekadar ve kahraman kadına meb’us seçmek ve seçilmek hakkı verilmez olur muydu?

Daver'e göre Avrupa'da pek çok ülkenin kadına vermediği hakkı Cumhuriyet hükümeti vermiştir. TBMM'de artık milletin diğer 'yarısının' da temsil edildiğini belirten Daver'e göre Türkiye demokrasi konusunda oldukça ilerlemiş bir ülke haline gelmiştir (Daver, Cumhuriyet: 1934). 25 Aralı 1934 tarihli nüshada ise "Hem Nalına Hem Mıhına",2 köşesinde yayımlanan "Peçenin gecesinden kurultayın güneşine" başlıklı makalede, Türk kadınlarına milletvekili seçme ve seçilme haklarının verilmesi dolayısıyla Fransız kadınlarının Paris Türk Büyükelçiliği’ne ulaştırdıkları kutlama mesajları hakkında bilgi verilmektedir. Makalede, Fransız kadınlarının mesajlarında bir imrenme ve kıskançlık hissedildiği vurgulanmaktadır. Cumhuriyet'in Türk kadınını on yıl içinde peçenin karanlığından kurtardığının belirtildiği makalede yalnız Fransız değil, oldukları yerde saydıkları için Avrupa kadınlarının çoğunun Türk kadınına imrenerek baktıkları vurgulanmaktadır. Yazı şöyle devam etmektedir (Cumhuriyet, 1934):

Türk kadını daha dün peçenin karanlığı içinde saklı, kafesin arkasında tutsak (esir) idi; Fransız kadınları, dört tanesini bir erkeğin alabildiği Türkiye'deki kız kardeşlerine acıyıp duruyorlardı. Bugün ise iş tersine dönmüştür. Türk kadını, yıllardanberi, bir türlü, saylav seçmek ve seçilmek hakkına kavuşamamış olan Fransız kadınına karşı bir acıma duyabilir.

Daver'in anlatımı bir miktar abartılı sayılsa bile Tekeli'ye göre aynı dönemde Fransız kadınlarının henüz siyasal haklara sahip olamadığı ve bu haklar için

\footnotetext{
2 Üçüncü sayfada "Hem Nalına Hem Mıhına" köşesi, genelde imza olarak çekiç tutan bir el sembolü ile bazen de Abidin Daver imzasıyla çıkmaktadır (Köktaner, 2005: 29).
} 
İngiltere'de şiddetli bir mücadele verildiği halde İngiliz kadınlarının parlamentoda 1918-1935 yılları arasında yüzde 0,1 ile yüzde 2,4 arasında temsil imkânı bulması (akt. Kadığlu, 1998: 94) hiç kuşkusuz Türk kadının değişen konumu açısından Cumhuriyetin bir başarısıdır. Ancak Türk kadınları bu hakları kazanabilmek için ihtilal döneminden beri ön saflarda hareket eden Fransız kadını ya da İngiliz kadınları gibi büyük bir mücadele içine girmemiştir. Kadıoğlu'nun belirttiği gibi (Kadıŏlu, 1998: 95) tüm modernleşme hareketindeki genel karakteristik özellikler Türk kadının hakları konusunda da geçerlidir yani tepeden inmedir. 1923'teki tabandaki küçük hareket, Türk Kadınlar Birliği'nin kuruluşu ile devam etse de baskılar bizzat kadınlar tarafından gelişecek bir hareketi engellemiştir. Tek Parti'nin kendisi dışındaki tüm oluşumları tasfiye ettiği ve yenilerinin kurulmasına izin vermediği, herşeyi parti güdümünde tuttuğu bir dönemde de zaten kadınlara sağlanan haklar yeterli görülmüştür. Diğer taraftan Berktay'ın da belirttiği gibi kadınlar egemen ulusçu ideolojiyi içselleştirebilmişlerdir. Tüm hakların kazanıldığı yanılsaması nedeniyle bağımsız bir bilinç ve hareket gelişmediği için bu içselleştirme nedeniyle egemen ataerkil yapıda aslında bir değişiklik olmamıştır. Berktay’a göre imgeler, kalıplar ve kurallar kadınlar tarafından içselleştirildiğinde onları belki herşeyden daha fazla baskı altında tutacaktır (Berktay, 1998: 5). Böyle bir imaj toplumda yaratıldığında ise aynı Ercümend Ekrem Talu ve Abidin Daver'in 1935'te kaleme aldığı makalelerindeki gibi 'mutluluk' tabloları ortaya çıkarılabilecektir. Paris'te Matmazel Jan Veniel adlı bir kadının zabıta memuru olması üzerine Fransız gazetelerinin yaptıkları yayınları inceleyen Talu, Fransız kadını ile Türk kadınını karşılaştırır. Talu'nun amacı aslında Türk inkılabı sayesinde Türk kadınlarının eriştiği çağdaşlık seviyesini vurgulamaktır. Piyer Loti'nin 'Les Desenchantees' adlı

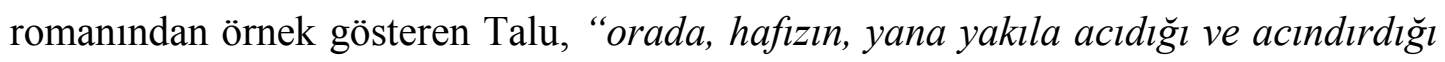
Türk kadınının, o tarihten sonra aldı̆̆ lütfunda bulunan her cihetçe üstün hemcinslerinin bugün muvaffatiyet diye kaydettikleri hadiseyi ölçüyor" diyerek Fransa'daki gelişmeyi "Kadınlık için ne mühim muvaffakiyet değil mi? "' ifadeleriyle bir bakıma küçümsemektedir. Fransız kadınlarıyla Türk kadınları arasındaki farkın baş döndürecek bir seviyede olduğunu belirten Talu, Türk kadının daima ileriye doğru yürüdüğünü vurgulamaktadır (Talu, Cumhuriyet:1935): 
Muallim, hekim, avukat, memur, dişçi, kimyager, belediye azası, hakim, muhtar, idareci, müşavir... Türk kadını bu mesleklerin hepsinde daima en mümtaz mevkii edindi, en derin ve samimi saygılarını kazandı. Paris'in enchanteeleri, terzi dükkânlarında elbise seçmekte meşgulden, Türkiye'nin deenchanteeleri saylav seçiliyorlar, gösterdikleri yüksek kabiliyet ve ehliyetin layık karşılığı olarak Millet Meclisi'ne giriyor, memleketin mukadderatına hükmedecek mevkie geçiyorlar. (...) Paris'te bir matmazel, tecrübe kaydıyla polis olmuş diye, matbuat birbirine giriyor. Bizim kadınlarımız saylav oluyorlar... Biz niçin bayram etmeyelim?

Ve Şubat 1935'te Abidin Daver bir başka makalesinde Türk kadınlarına şöyle seslenir: “Türk kadını sevin ve kıvanç duy!” (Daver, Cumhuriyet: 1935):

Çünkü on sene evvel çarşaf endamını, peçe yüzünü, kafes benliğini, harem varlığını bir ayıp gibi dünyadan gizliyordu. O zaman Fransız kadını nice yüz yılların verdiği hürriyetle serbest yaşıyordu. On sene içinde, sen haremden çıktın, kafesi kırdın, çarşafi attın, peçeyi yırttın. Savaş günlerinde, erkek kalmadığı için, saltanat seni yalnız sokak süpürücülüğüne ve posta gişesinde pul saymaya layık görmüştü. Cumhuriyet rejimi ise, seni erkeğin yanına oturttu -gücüne gitmezse diyelim ki- erkeğin yanına yükseltti. Erkek her ne öğreniyorsa sen de öğrendin. Erkek ne yapıyorsa sen de yaptın, erkek ne olabiliyorsa sen de oldun.

Mustafa Kemal Atatürk, 31 Ocak 1923’te İzmir'de, aralarında kadınların da bulunduğu bir topluluğa hitaben yaptığı konuşmada hayatın çalışmak olduğunu vurgulamaktadır. Atatürk “Kadının, en büyük görevi, analıktır” (Goloğlu, 2009:163) demektedir. Çünkü ona göre ilk eğitim ana kucağında başlamaktadır. Kadının annelik görevini, onun, 'doğru' şekilde çocuk yetiştirmesiyle yerine getirilebileceği algısında yatmaktadır. Çağdaş değerlerle yetişmiş bir kadın hiç kuşkusuz yetiştiği değerlere uygun şekilde çocuk büyütecektir (Bakacak, 2009: 635). Bu ise modern bir devletin geleceğinin teminatı olarak görülmektedir. Mustafa Kemal Atatürk bu bağlamda kadınların 'bilgin' olmalarını ve erkeklerin geçtikleri bütün öğrenim derecelerinden geçmelerini istemektedir. 14 Ekim 1925’teki İzmir Kız Öğretmen Okulu'nda yaptığı konuşmada ise Türk kadının, "dünyanın en aydın, en erdemli ve en ağır kadını” olması gerektiğini belirtmiştir (Goloğlu, 2009: 164-165). Cumhuriyet gazetesi ise bu söylemleri Yusuf Ziya'nın kalemiyle okuyucularına maddeler halinde sunmaktadır (Ziya, 1932):

Türk kadını, vatan istediği gün, hudutlara, çocuklarının iskeletinden aşılmaz siperler çeken fedakâr anadır!

Türk kadını, tehlike ve ateş gününde, sırtında cephane ve erzak taşıyan bir görüllü neferdir.

Türk kadını, erkeğine, çocuğuna, yuvasına candan bağlı bir dişi kuştur.

Türk kadını, hastanede operatörlük, mektepte hocalık, fabrikada amelelik, tarlada rençberlik etmesini bilen, ekmeğini alın teri, göz nuru, bilet kuvvetile kazanmaya alışmış, içtimai bünyenin faal bir uzvudur. 
Türk kadını, Timur'ları, Cengiz'leri, Mete'leri, Mustafa Kemal'leri yetiştirmiş en büyük terbiyecidir.

Türk kadınının, dünya kadınlarından geri kaldığı bazı san’atlar vardır. Beynelminel bir fahişe pazarı olan Paris’te Türk kadınını göremezsiniz. (...) Fakat buna mükabil, Rue de la Paix'de, dünya zerafetine hükmeden büyük moda müesseselerinin başına geçmiş Türk kadınları var!

21Kasım 1931'de dönemin ünlü edebiyat çevirmeni Şaziye Berrin Hanım ile bir mülakat yapan gazete, Türk kadınının aile içi görevlerini net bir biçimde sütunlarına yansıtır. İyi bir kadın yuvasının refahı için çalışan, kocasını çok sevmesini bilen, en büyük meziyeti şefkat olan kişidir. Şaziye Berrin'e göre kadınlar "ev denilen o küçük kâinatı" yaratmaya ve yükseltmeye, ülkesine yararlı evlatlar yetiştirmeye mecburdurlar (Fehmi, Cumhuriyet: 1931). Gazete 29 Ocak 1935 tarihinde Çapa Kız Muallim Mektebi felsefe öğretmeni Nebahat Hamdi Hanım’la bir mülakat gerçekleştirmiştir. Bu yazıda vurgulanan en önemli nokta ise kadının eğitimi üzerinedir (Cumhuriyet: 1935):

Memleket kadınlığının umumi hayat seviyesini yükseltmek, kültürünü, ev bakımını, çocuk yetiştirmesini öğretmek lazımdır. Yoksa manikür, pedikür, sinema, balo, dans ve moda, lüks, yüksek iskarpin, hizmetçi, ahçı, porda, ruj, altı aylık ondülasyon bunlar kadınlığı kurtarmaz, bilakis pasif hayata alıştırır. Bize lüks ihtiyaçlar düşünen kadın değil, verilen hakları kullanmayı ve vazifelerini yapmasını bilen kadın lazımdır.

Haber ve yorumlarda, tasarruf konusunda da kadınlara müsrif olmamaları öğ̈̈tlenmekte ve kadınlar göreve davet edilmektedir. Yunus Nadi’nin 20 Haziran 1932'deki başyazısının başlığı bu bağlamda anlamlıdır: “Ev kadını, Hayat kadını”. Nadi, İsmet Paşa Kız Enstitüsü'nün çalışmaları hakkında bir yazı kaleme almak istemiştir. Ancak enstitü hakkında bilgi vermeden önce uzun uzun kadınların ev ekonomisinde dikkat etmeleri gereken noktaları hatırlatarak sözü tasarrufa getirir (Nadi, Cumhuriyet: 1932):

Bir ev hanımı için kendisinin ve çocuklarının bütün elbise ve çamaşır ihtiyaçlarını büyük bir bilgi ile bizzat yapmadaki zevke had ve payan tasavvur olunabilir mi? Halbuki mesele yalnız zevk meselesi değildir. Aile bütçelerinin çoğunu tahrip eden bir amil de şüphesiz bilgisizliktir. Herşeyi hariçten satın alacak ve her işini başkasına gördürmek mecburiyetinde kalacak bir hanımın aile bütçesi daima dar olacaktır. Evinizin penceresine asacağınız perdeleri hazır olarak da alabilirsizin, bizzat kendiniz de yapıp asabilirsiniz, hatta eğer işin hiç te büyük bir şey olmayan sanat sırrına vakıfsanız başkasına yaptıracağınızdan bin kere daha güzelini bizzat kendiniz yaparsınız. (...) Bir işi kendiniz görmekle başkasına yaptırmak arasında masraf itibariyle ne fark olur bilir misiniz? Laakal yarı yarıya. 
Gazete 14 Aralık 1933'te yayımladığı bir başka yazıda ise tasarruf konusunda en büyük vazifeyi açıkça Türk kadınlarına yüklemektedir. Tasarrufa ilişkin uyarıların yer aldığg yazıda kadınlara hitap edilerek şöyle denilmektedir (Cumhuriyet, 1933):

Türk kadını; istihsalde, istihlakte ve tasarrufta vazifesini yapmazsa, en büyük mes'ul odur. Milli tarih karşısında bundan dolayı mes'ul tutulan Türk kadınları vardır. Osmanlı devrinde İmparatorluk inhitata sürüklenirken kadınların tasarrufta dikkatsizliği yüzünden Türk ailelerinin ne elim vaziyetlere düştüklerini öğrenmek için tarih okumaya lüzum yoktur.

Ercümend Ekrem Talu da 1934 yılında yazdığı makalesinde kadını açıkça tutumlu olmaya yönlendirmektedir: "Tutumlu kadın bir ev içinde değer biçilemez bir nimettir. Kocasını gözeten, çocuklarının gelecek günlerini düşünen ev kadını kamunun saygısını kazanır" (Talu, Cumhuriyet: 1934).

Nilüfer Göle'ye göre, modernleşme projesinde kadınlar, bir yandan ulusal aktörler, anneler, eğitimciler, işçiler ve hatta savaşçılar olarak toplumsal hayata daha çok katılmaya davet edilir. Fakat diğer taraftan kültürel olarak 'kabul edilebilir' kadın davranışları ön plana çıkarılmıştır. Ona göre, yeni kurulan Türkiye'de kadının toplumsal yaşama girişi onun erkek kimliğine büründürülmesiyle meşrulaştırılmıştır. (Göle, 2011: 108-109). 21 Kasım 1931 tarihindeki nüshada Şaziye Berin Hanım’ın “erkeğin kadınlaşması müstekrehtir” ifadeleri Göle’nin yaklaşımı açısından değerlendirilebilir. Şaziye Berin, erkek vücudunu iki çizgi ile yapılmış bir heykele benzetir ayrıca sade ve güzel olduğunu söyler. Fakat ona göre kadın vücudu bunun tersidir (Fehmi, Cumhuriyet: 1931):

Kadın vücudu ana olmak için yaratılmıştır, teferrüatla doludur. Kadın vücudu hislerimizi tahrik, fakat erkek vücudu zekâmızı hayran eder. Kadının erkeğe benzemek hevesini ne kadar beğenirsem erkeğin kadına benzemek cinnetini o kadar müstekreh bulurum.

Gazetenin pilot Bediya Hanım ile yaptığı bir mülakatta ise, "Teyyareden uzak olduğum zamanlar motördeki hintyă̆ı kokusu bile burnumda tüter... ”(Cumhuriyet, 1933) sözlerinin yine dikkat çekici bir şekilde verilmesi de Göle’nin yaklaşımını hatırlatmaktadır. 1933 yılındaki en önemli tartışmalar arasında yer alan kadınların askerlik meselesi ile ilgili yayımlanan makalelerde de benzer ifadelere rastlamak mümkündür. Mustafa Kemal Atatürk'ün 1933 yılında, Hukuk Fakültesi’nde bir kız öğrenciye "Niçin mebusluk istiyorsunuz da askerlik istemiyorsunuz?" (Goloğlu, 2009:165) sorusuyla alevlenen tartışmalara Cumhuriyet gazetesi de katılmıştır. 7 
Kasım 1933'te yayımlanan bir makalede konu derinlemesine tartışılmış ve kadınların asker olmayı istemekte haklı olduklarına kanaat getirilmiştir (Cumhuriyet, 1933):

... Kadıköy K1z Orta mektebi talebesi, borazanları, trampetleri, fifreciler ile yürüyüşlerindeki keskinlik, sertlik ve beraberlik itibariyle değil, ancak askeri liselere kıyas edebilirdi. Kızlarımızın resmigeçitte gösterdikleri erkeklerden üstün mükemmeliyete ve askeri intizama bakılırsa, asker olmak istemekte yerden göğe kadar hakları vardır. (...) Kadının asker olup olamayacağı bahsinde, gözlerimizin önüne hep büyük şehirlerin birbiriyle moda muharebesi yapan nazlı hanımları geliyor. Fakat bu memleketin 8 milyon kadını içinde manikürlü, pembe ve yumuşak eller 80.000 bile değildir, geriye kalan milyonlarca muhterem el ise sapan, kazma ve kürek tutmaktan nasırlaşmıştır.

Yazar bakımlı kadınları küçük bir azınlığa indirgemekte ve ‘manikürlü' ellere olumsuz bir değer yüklemektedir. Diğer taraftan 'nasırlaşan' ellere, 'muhterem' ifadesinden de anlaşılacağı üzere olumlu bir değer yüklenmekte ve bu tür kadınların toplumun büyük bir kesimini oluşturduğu vurgulanmaktadır. Toska'nın belirttiği (Toska, 1998: 80) İstanbul ve Anadolu kadını ayrım bu yazıda adeta hayat bulmuş gibidir. Modernleşme projesinde "çaydan çaya koşan", moda ve dans tutkunu İstanbul kadınları dışlanmıştır ve egemen görüşe göre Türk kadınını asla temsil edemez haldedir. Oysa geçmişten beri yaşadıkları deneyimlerle İstanbul kadınları, Anadolu kadınlarına göre yaşayış bakımından daha özgür ve örgütlüdürler. Halide Edip'in bu dışlanmaya karşı Akşam gazetesinde verdiği cevap, İstanbul kadın hareketine desteğini gözler önüne serer: "Çaylara gitmek, modaya meraklı olmak, hatta dans etmek bir kadının memleketine ait meselelerde ciddi düşünemeyeceğini ifade etmez. Memleketin bütün yükünü aziz omuzlarında taşıyan taşra kadınının çoğunluğunun menfaat ve hakkını da şehirdeki kadınlar inceleyecek ve savunacaklardır" (Çalışlar, 2011:307). Halide Edip'in bu karşı çıkışı ne yazık ki bir destek bulamayacaktır. Cumhuriyetin nimetlerinden en çok yararlanan ve en çok içselleştiren kesim İstanbul kadınları olmasına rağmen dönemin kadını dişiliği yok edilmiş kadındır. Yani kadının özgürce davranması ve giyinmesi hiçbir zaman onaylanmamıştır. Mustafa Kemal Atatürk bile, 21 Mart 1923’te Konyalı kadınlara hitap ederken, bazı kadınları Avrupai tutum ve davranışları taklit ettikleri ve giyim tarzında aşırıya kaçtıkları için eleştirmiştir. Kadınlar iş yaşamında namus ve iffetini koruması konusunda uyarılmıştır. (Arat, 1998: 55). Önemli olan görev bilincini içselleştirmiş kadındır. 5 Şubat 1935 tarihinde Cumhuriyet gazetesinin Şükriye Unkınay’la yaptığı mülakatta kayda geçen aşağıdaki cümleler; Cumhuriyetin yeni 
kadınının, Kadıŏglu'nun da belirttiği gibi (Kadığlu, 1998: 96) iş ve aile yükünü omuzlayan bir kahraman olduğu kadar Batılı kadının cinselliğini dışlayan bir yapıda olduğunu ortaya koymaktadır (Cumhuriyet, 1935):

Anadolu kadını nasırlı elleri, orak biçmekten taş gibi katılaşmış teni ve cefaya alışkın vücudu ile 'ben asker olurum, ben ölümden korkmam ve savaşa gitmeye hergün hazırım' diyor gibidir. İşte bu kadın gene icabında asker olur.

\section{Sonuç}

Yeni kurulan Cumhuriyet rejimi, Osmanlı'dan gelen ve İslami kültürle beslenen gelenekleri, tüm ideolojik aygıtları devreye sokarak yıkmaya çalışmış ve bunu yaparken Türk kadınını çağdaş bir konuma getirmeyi hedeflemiştir. Kadın hakları bir simge olarak kullanılarak yıkılmak istenen geçmişin kökten silinmesi istemi doğrultusunda bir devlet politikası halinde tepeden inme biçimde topluma benimsetilmeye çalışılmıştır. Cumhuriyet yurttaşının zihinsel dönüşümü sağlanmak istenirken Cumhuriyet kadınının da arzu edilen örnekleri Türk basını aracılığıyla yaygınlaştırılmıştır. Kökeni Orta Asya'ya uzanan ve iktidar tarafından seçilen fedakâr Anadolu tipi Türk kadınının zihinlerde oluşturulmak istenen yeni imajı, ne çok açık ne çok kapalı giyim tarzı ile sosyal hayatın içinde, kültürel ve sportif faaliyetlere katılan, iyi eğitilmiş fakat bütün bunları ulusal kalkınma prensibi doğrultusunda, erkekle omuz omuza yaşamayı bir görev bilinci halinde içselleştirmiş, simgesel düzeyde ise tüm dünyaya Türkiye Cumhuriyeti’nin çağdaş bir devlet olduğunu kanıtlamak zorunda olan kadındır. Diğer taraftan toplum içinde varolabilmesi, cinselliğinin yok edilmesine bağlıdır. Bu bağlamda kadınların, Osmanlı'nın gündelik sıkı ve katı kalıplarından Cumhuriyet rejimi sayesinde kurtulduğunu söylemek doğrudur fakat kurtuluşu ya da kurtuluşun koşullarını kendisi ne kadar talep etmiştir? Tüm eleştirel görüşlere karşın talebi üretip mücadele edecek ve bu mücadeleyi yaygınlaştırabilecek geniş bir kadın kitlesi olmadığından kadın haklarının da egemen bir erkek azınlığın dışında gelişmesi zaten pek de mümkün değildir. Tabandan, bir kaç küçük hareket dışında bir talebin olmaması, Halide Edip'in de savunduğu gibi daha Cumhuriyet kurulmadan evvel bir takım çabalar gösteren İstanbul kadınlarının gözden düşmesi hatta tasfiye edilmesi, 1930'lu yıllara gelindiğinde ise tek parti ile özdeşleşen siyasette parti dışında bir oluşuma müsade edilmemesi, Türkiye'de kadın haklarının devletin arzusu ve kontrolü dışında 
gelişmesini engellemiştir. Toplumun değişim ayarını elinde bulunduran iktidarın kadınlara dair istenen örnekleri topluma benimsetme sürecinde Cumhuriyet gazetesi yoğun faaliyette bulunmuştur. Gazetedeki tüm yazılar neredeyse erkekler tarafından kaleme alınmıştır ve bu kalemlere göre Türk kadını, dişiliği ile ön planda değil tam tersi yüceltilen görevleriyle önde olmalıdır. Gazete, dönemin iyi eğitimli ve meslek sahibi kadınlarıyla yaptığı mülakatları sütunlarına yansıtsa bile mülakatı gerçekleştirenler ve bu gazetecilerin sorduğu sorular ile almak istedikleri cevaplar egemen söyleme aykırılık teşkil etmeyecek niteliktedir. Haber ve makalelerin, bir kadın hareketini ortaya çıkaracak bilinçlenmeyi teşvik etmek için değil, Türk kadınının 'arzu edilen' yeni imajının yaratılmasında iktidara destek olmak amacı ile hazırlandığı açıkça anlaşılmaktadır.

\section{KAYNAKÇA}

AHMAD, Feroz (2009). Modern Türkiye'nin Oluşumu, İstanbul: Kaynak Yayınları.

ALTUN, Fahrettin (2011). Modernleşme Kuramı: Eleştirel Bir Giriş, İstanbul: Küre Yayınları.

ARAT, Zehra (1998). "Kemalizm ve Türk Kadını”, (Editör) Ayşe Berktay Hacımirzaoğlu, 75 Yılda Kadınlar ve Erkekler, İstanbul: Türkiye Ekonomik ve Toplumsal Tarih Vakfi.

BAKACAK, Ayça (2009). "Cumhuriyet Dönemi Kadın İmgesi Üzerine Bir Değerlendirme”, Ankara, Ankara Üniversitesi Türk İnkılap Tarihi Enstitüsü Atatürk Yolu Dergisi, 627-638.

BALİ, N. Rifat (t.y.) Tek Parti Döneminde Gazete Tirajları, http://www.rifatbali.com/images/stories/dokumanlar/tek_partili_donemde_ga zete_tirajlari.pdf, Erişim Tarihi: 14.09.2012.

BERKTAY, Fatmagül (1998). "Cumhuriyet'in 75 Y1llı Serüvenine Kadınlar Açısından Bakmak", (Editör) Ayşe Berktay Hacımirzaoğlu, 75 Yılda Kadınlar ve Erkekler, İstanbul: Türkiye Ekonomik ve Toplumsal Tarih Vakfi. 
ÇALIŞLAR, İpek (2011). Biyografisine Sığmayan Kadın Halide Edip, İstanbul: Everest Yayınları

DEMİR, Vedat (2007). Türkiye'de Medya ve Siyaset İlişkisi, İstanbul: Beta Yayınlar1.

DURAKBAŞA, Ayşe (1998). "Cumhuriyet Döneminde Modern Kadın ve Erkek Kimliklerinin Oluşumu: Kemalist Kadın Kimliği ve Münevver Erkekler”, (Editör) Ayșe Berktay Hacımirzaoğlu, 75 Yılda Kadınlar ve Erkekler, İstanbul: Türkiye Ekonomik ve Toplumsal Tarih Vakfi.

DURNA, Tezcan (2009). Kemalist Modernleşme ve Seçkincilik, Ankara: Dipnot Yayınlar1.

ELİUZ, Ülkü(2008). "Meşrutiyete Giden Süreçte Yeni Kadın İmgesi: Fatma Makbule Leman”, Bilig Dergisi, 2008, Say1 47, 177-192.

GOLOĞLU, Mahmut (2009). Türkiye Cumhuriyeti Tarihi 1931-1938 Tek Partili Cumhuriyet, İstanbul: Türkiye İşbankası Kültür Yayınları.

GÖLE, Nilüfer (2011). Modern Mahrem, İstanbul: Metis Yayınları.

GÜNGÖR, Nazife (2011). İletişim, Kuramlar ve Yaklaşımlar, Ankara: Siyasal Kitabevi.

İNCE, Gökçen B.(2010). "Erken Cumhuriyet Dönemi Basınından Üç Portre, Üç Fikir: Sabiha (Zekeriya) Sertel, Ahmet Emin Yalman, Nadir Nadi”, Tercüman-1 Ahval'in 150. Y1lında İstanbul'da Fikir Gazeteciliği Sempozyumu (21-22 Ekim 2010), Ed. Belkıs Ulusoy Nalcığlu, İstanbul.

KADIOĞLU, Ayşe (1998). “Cinselliğin İnkarı: Büyük Toplumsal Projelerin Nesnesi Olarak Türk Kadınları", (Editör) Ayşe Berktay Hacımirzaoğlu, 75 Yılda Kadınlar ve Erkekler, İstanbul: Türkiye Ekonomik ve Toplumsal Tarih Vakfi.

KANDIYYTİ, Deniz (2011). Cariyeler Bacılar Yurttaşlar, İstanbul: Metis Yayınları. 
KANTER, Beyhan(2010). “Osmanlı Basın Hayatında Kadın Yazarlar”, Tercüman-1 Ahval'in 150. Y1lında İstanbul'da Fikir Gazeteciliği Sempozyumu (21-22 Ekim 2010), Ed. Belkıs Ulusoy Nalcıŏlu, İstanbul.

KAYNAK, Muhteşem(t.y.). Atatürk Döneminde Büyüme Ve Beşeri Sermayenin Geliştirilmesine Yönelik Girişimler Ve Günümüz İçin Kısa Bir Değerlendirme, http://www.muhtesemkaynak.com/59.pdf, Erişim Tarihi:02.11.2013.

KIRKPINAR, Leyla (1998). “ Türkiye'de Toplumsal Değişme Sürecinde Kadın”, (Editör) Ayşe Berktay Hacımirzaoğlu, 75 Yılda Kadınlar ve Erkekler, İstanbul: Türkiye Ekonomik ve Toplumsal Tarih Vakfi.

KOCABAŞOĞLU, Uygur (2010). İkinci Meşrutiyet'in Birinci Meşrutiyeti: Matbuat, (Editör) Hakan Aydın. İkinci Meşrutiyet Devrinde Basın ve Siyaset, Konya: Palet Yayınları.

KÖKTENER, Aysun (2005). Bir Gazetenin Tarihi: Cumhuriyet, İstanbul: Yapı Kredi Yayınları.

NALCIOĞLU, Belkıs (2004). Azerbaycan Siyasi Muhaceretinin İstanbul'daki Basın Etkinliklerinin Kamuoyu Oluşturmadaki Rolü, İstanbul: İstanbul Üniversitesi İletişim Fakültesi Yayınları.

OKTAR, Tiğince (1998). Osmanlı Toplumunda Kadının Çalışma Yaşamı, İstanbul: Bilim Teknik Yayınları.

ÖZGENTÜRK, Nebil (2008). Cumhuriyetten Günümüze Basının Kısa Tarihi, İstanbul: Alfa Yayınları.

ÖZDEMIR, Murat (2010). Nitel Veri Analizi: Sosyal Bilimlerde Yöntembilim Sorunsalı Üzerine Bir Çalışma, Eskişehir Osmangazi Üniversitesi Sosyal Bilimler Dergisi, 323-343.

ŞİRIN, Funda S. (2010). "Ulus Devlet İnşasında Basının Rolü: Falih Rıfkı Atay”, Tercüman-1 Ahval'in 150. Yilında İstanbul'da Fikir Gazeteciliği Sempozyumu (21-22 Ekim 2010), Ed. Belkıs Ulusoy Nalcığlu, İstanbul. 
TANILLİ, Server (2006). Ne olursa olsun savaşıyorlar : kadın sorununun neresindeyiz?, İstanbul: Alkım Yayınevi.

TAZEGÜL, Murat (2005). Modenleşme Sürecinde Türkiye, İstanbul: Babil Yayınları.

TOSKA, Zehra (1998). "Cumhuriyet'in Kadın İdeali: Eşiği Aşanlar ve Aşamayanlar”, (Editör) Ayşe Berktay Hacımirzaoğlu, 75 Yı1da Kadınlar ve Erkekler, İstanbul: Türkiye Ekonomik ve Toplumsal Tarih Vakfı.

YAYLAGÜL, Levent (2006). Kitle İletişim Kuramları, Ankara: Dipnot Yayınları.

YILDIRIM, Ali ve ŞİMŞEK, Hasan (2005). Sosyal Bilimlerde Nitel Araştırma Yöntemleri, Ankara: Seçkin Yayınları.

ZÜRCHER, Erik J. (2012). “Kemalist Cumhuriyet'te Kurumların İnşası: Halk Fırkası'nın Rolü”, Türkiye ve İran'da Otoriter Modernleşme, Der. Touraj Atabaki-Erik J. Zürcher, İstanbul: İstanbul Bilgi Üniversitesi Yayınları.

\section{Gazete}

Cumhuriyet Gazetesi(1930). “İlk Türk kadın şöförün anlattıkları”, 17 Ocak 1930.

Cumhuriyet Gazetesi(1930). "Türk Kadını Hakkında Bir Makale”, 14 Haziran 1930.

Cumhuriyet Gazetesi (1932). “Türkiye'de Feminizm”, 16 Kasım 1932.

Cumhuriyet Gazetesi(1933). “Türk Kadınını Zaferi”, 3 Şubat 1933.

Cumhuriyet Gazetesi (1930). "Kadınlarımız Hayata Muvaffak Oluyorlar”, 9 Ağustos 1930.

Cumhuriyet Gazetesi(1931). “Operatör Suat Hanım”, 16 Mart 1931.

Cumhuriyet Gazetesi(1931). “İlk kadın köy muhtarı”, 15 Kasım 1931.

Cumhuriyet Gazetesi (1933). “İlk Teyyareci Türk kadını”, 29 Temmuz 1933.

Cumhuriyet Gazetesi (1933). “Kadın ve askerlik”, 7 Kasım 1933.

Cumhuriyet Gazetesi (1933). "İstihlak ve tasarrufta en büyük vazife kadınlarımıza düşmektedir”, 14 Aralık 1933. 
Cumhuriyet Gazetesi (1934). "Peçenin gölgesinden kurultayın güneşine”, 25 Aralık 1934.

Cumhuriyet Gazetesi (1935). "Kadın saylav olursa”, 28 Ocak 1935.

Cumhuriyet Gazetesi (1935). "Muallim Saadetle Şükriye içtimai ve sosyal hayatta kadının durumunu anlatıyorlar”, 5 Şubat 1935.

DAVER, Abidin (1934). "Türk Kadını Büyük Millet Meclisinde”, Cumhuriyet Gazetesi, 7 Aralık 1934.

DAVER, Abidin (1935). “Türk kadını sevin ve kıvanç duy!”, Cumhuriyet Gazetesi, 7 Şubat 1935.

FEHMİ, Cevat (1931). “Şaziye Berin Hanım Kadınlara Düşman!”, 21 Kasım 1931.

İNAN, Afet (1937). “Türk Kadını”, Ulus Gazetesi, 14 Şubat 1937.

NADİ, Yunus (1930). “Güzellik ayıp bir şey değildir”, Cumhuriyet Gazetesi, 13 Ocak 1930.

NADİ, Yunus (1930). “Haremden gümüş köprüye”, Cumhuriyet Gazetesi, 30 Ocak 1930.

NADİ, Yunus (1930). “Kadınlarımızın İntihap Hakkı”, Cumhuriyet Gazetesi, 4 Nisan 1930.

NADİ, Yunus (1931). “Güzellik İntihabının Münakaşaları”, Cumhuriyet Gazetesi, 24 Ocak 1931.

NADİ, Yunus (1932). “Türk Kadını, Cemiyette ve Dünyada”, Cumhuriyet Gazetesi, 1 Eylül 1932.

NADİ, Yunus (1932). “Türk Kadını”, Cumhuriyet Gazetesi, 29 Ağustos 1932.

NADİ, Yunus (1932). “Ev kadını, Hayat kadını”, Cumhuriyet Gazetesi, 20 Haziran 1932.

NADİ, Yunus (1933). “Cumhuriyet devrinde kadın”, Cumhuriyet Gazetesi, 10 Ekim 1933. 
NİHAL, Şükufe (1935). "Dünyanın her yerinde kadının kurtuluşu yakındır", 15 Nisan 1935.

ÖZTÜRK, Halil (1935). “Türk Kadını”, Cumhuriyet Gazetesi, 22 Ocak 1935.

REŞAT, A. (1933). “Amerika ve Fransa' da onuncu yıl bayramımız”, Cumhuriyet Gazetesi, 20 Kasim 1933.

SELÇUK, F. (1933). “Kadın asker olabilir mi?” Cumhuriyet Gazetesi, 8 Kasım 1933.

TALU, Ercümend (1934). “Tutum Haftası”, Cumhuriyet Gazetesi, 12 Aralık 1934.

TALU, Ercümend (1935). “Mutlu Kadın”, Cumhuriyet Gazetesi, 2 Ocak 1935.

ZIYYA, Yusuf (1932). “Türk Kadını”, Cumhuriyet Gazetesi, 3 Ağustos 1932. 